\title{
PENGARUH MODEL PEMBELAJARAN PROBING PROMPTING BERBANTUAN MULTIMEDIA TERHADAP HASIL BELAJAR IPA SISWA KELAS V SD
}

\author{
Ni Pt Rasni Karwati ${ }^{1}, \mathrm{Km}$ Ngurah Wiyasa ${ }^{2}$, I Kt Ardana $^{3}$ \\ 1,2,3 Jurusan Pendidikan Guru Sekolah Dasar' Universitas Pendidikan Ganesha, Singaraja \\ e-mail: rasnianiy@gmail.com ${ }^{1}$,ngrh.wiyasa@undiksha.ac.id ${ }^{2}$, iketut.ardana@undiksha.ac.id ${ }^{3}$
}

\begin{abstract}
Abstrak
Penelitian ini bertujuan untuk mengetahui perbedaan yang signifikan hasil belajar IPA antara siswa kelas V SD Gugus I Kecamatan Kuta Utara tahun ajaran 2017/2018 yang mengikuti pembelajaran probing prompting berbantuan multimedia dan yang mengikuti pembelajaran konvensional. Desain penelitian ini adalah penelitian eksperimen semu dengan rancangan nonequivalent control group design. Populasi penelitian ini adalah seluruh siswa kelas V SD yang masih menerapkan KTSPdi Gugus I Kecamatan Kuta Utara, yang terdiri atas 10 kelas dengan jumlah 339 siswa. Pengambilan sampel dilakukan dengan teknik random sampling. Sampel penelitian ini adalah siswa kelas VB SD No. 7 Dalung dengan jumlah 36 siswa sebagai kelompok eksperimen dan siswa kelas VB SD No. 4 Dalung dengan jumlah 28 siswa sebagai kelompok kontrol. Pengumpulan data dilakukan dengan menggunakan metode tes dalam bentuk tes objektif pilihan ganda biasa.Data hasil belajar IPA siswa dianalisis menggunakan ujit. Dilihat berdasarkan nilai rata-rata kelompok eksperimen $=80,89>$ kelompok kontrol $=72,85$, yang berarti tedapat pengaruh model pembelajaran probing prompting berbantuan multimedia terhadap hasil belajar IPA. Berdasarkan uji hipotesis diperoleh $\mathrm{t}_{\text {hitung }}=4,517>\mathrm{t}_{\text {tabel }}=2,000$ dengan $\mathrm{dk}=62$ dan taraf signifikansi $5 \%$. Berdasarkan kriteria pengujian maka $\mathrm{H}_{0}$ ditolak dan $\mathrm{H}_{\mathrm{a}}$ diterima, sehingga dapat diinterpestasikan bahwa terdapat perbedaan yang signifikan hasil belajar IPA antara kelompok siswa yang dibelajarkan menggunakan model pembelajaran probing prompting berbantuan multimedia dan kelompok siswa yang dibelajarkan menggunakan pembelajaran konvensional. Dengan demikian dapat disimpulkan bahwa model pembelajaran probing prompting berbantuan multimedia berpengaruh terhadap hasil belajar IPA siswa kelas V SD Gugus I Kecamatan Kuta Utara tahun ajaran 2017/2018.
\end{abstract}

Kata kunci: probing prompting, multimedia, hasil belajar IPA

\begin{abstract}
This research aims to determine the significance of the difference in science learning results between the group of fifth-grade students in Gugus I Elementary Schools, North Kuta District, in the school year of 2017/2018, that take lessons with the multimedia-assisted probing-prompting learning model and the group of students that take lessons with the conventional learning. The design of this research is a quasi-experimental research with the nonequivalent control group design. The population of this research are all the fifth-grade students of Gugus I Elementary Schools in North Kuta District that still implement the KTSP, which consists of 10 classes with a total of 339 students. The sampling is conducted using the random sampling technique. The sample in this research are the students of class VB in SD (Elementary School) No.7 Dalung, with 36 students as the experiment group and the students of class VB in SD No.4 Dalung with 28 students as the control group. The data collection is conducted using the test method in the form of the multiple choice objective test. The science learning results are analyzed using the $t$ test. Based on the average the experiment groups $=80,89>$ the control group $=72,85$, which means that the multimedia-assisted probing-prompting learning model has an influence on the science learning result. Based on the hypothesis test, tvalues $=4,517>$ ttable $=2,000$, with $d k=62$ and a significance level of 5\%. Based on the test criteria, $\mathrm{HO}$ is rejected and $\mathrm{Ha}$ is accepted. Thus, it can be interpreted there is a significant difference the science learning result between the group of students that were taught using the multimedia-assisted probing-prompting learning model and the students that were taught using the conventional learning. It can be concluded that the the multimedia-assisted probing-prompting learning model has an influence on the science learning result of the fifth-grade students in Gugus I Elementary School, North Kuta District, in the school year of 2017/2018.
\end{abstract}

Keywords : probing prompting, multimedia, science learning result 


\section{Pendahuluan}

Pada dasarnya pendidikan merupakan usaha sadar untuk menumbuhkan potensi sumber daya manusia (siswa) dengan cara mendorong dan memfasilitasi kegiatan belajar siswa. Berdasarkan Undang-undang Republik Indonesia Nomor 20 Tahun 2003 tentang Sistem Pendidikan Nasional Bab 1 Pasal 1, pendidikan didefinisikan sebagai usaha sadar dan terencana untuk mewujudkan suasana belajar dan proses belajar agar peserta didik secara aktif mengembangkan potensi dirinya untuk memiliki kekuatan spiritual keagamaan, pengendalian diri, kepribadian, kecerdasan, akhlak mulia, serta keterampilan yang diperlukan dirinya, masyarakat, bangsa dan negara. Melalui pendidikan seseorang diharapkan mampu membangun sikap dan tingkah laku serta pengetahuan dan keterampilan yang perlu dan berguna bagi kelangsungan dan kemajuan diri dalam masyarakat, bangsa, dan negara. Dalam rangka mewujudkan potensi diri harus melewati proses pendidikan yang diimplementasikan dalam proses pembelajaran. Proses pembelajaran adalah suatu proses interaksi siswa dengan guru serta materi pelajaran yang sedang berlangsung saat pembelajaran sesuai dengan kompetensi yang dituntut dalam kurikulum.

Pada proses pembelajaran, kurikulum menjadi salah satu acuan rencana tertulis proses pembelajaran. Kurikulum dalam Undang-undang Nomor 20 Tahun 2003 tentang Sistem Pendidikan Nasional dinyatakan sebagai seperangkat rencana dan pengaturan tujuan, isi, dan bahan pelajaran serta cara yang digunakan sebagai pedoman penyelenggaraan kegiatan pembelajaran untuk mencapai tujuan pendidikan tertentu. Kurikulum telah mengalami beberapa kali penyempurnaan yang dimulai tahun 1999 (penyempurnaan Kurikulum 1994), Kurikulum KBK tahun 2004, Kurikulum KTSP tahun 2006 dan yang terakhir adalah Kurikulum 2013. Namun belum semua sekolah dapat melaksanakan Kurikulum 2013 karena masalah kesiapan sarana prasarana sekolah. Khususnya di Bali, sekolah yang menerapkan K13 adalah sekolah berada di daerah Kodya Denpasar dan beberapa sekolah pilihan diluar daerah Denpasar dan lainnya masih menggunakan Kurikulum 2006 (KTSP/ Kurikulum Tingkat Satuan Pendidikan). Dalam KTSP standar kompetensi (SK) dan kompetensi dasar (KD) merupakan standar minimum yang harus dicapai oleh siswa dalam setiap mata pelajaran misalnya dalam mata pelajaran IPA.

Menurut Samatowa (2016) IImu Pengetahuan Alam (IPA) atau sains merupakan sebuah cabang ilmu pengetahuan yang berhubungan langsung dengan alam dan tingkah laku manusia dan juga merupakan sebuah mata pelajaran yang menuntut siswa untuk mengembangkan pola pikir dan kreativitas untuk tetap bertahan dalam kehidupan masyarakat yang terus menerus mengalami perubahan. IPA adalah usaha manusia dalam memahami alam semesta melalui pengamatan yang tepat sasaran, serta menggunakan prosedur, dan dijelaskan dengan penalaran sehingga dapat menarik kesimpulan. Dalam hal ini para guru, khususnya yang mengajar IPA di sekolah dasar, diharapkan mengetahui dan mengerti hakikat pembelajaran IPA, sehingga dalam pembelajaran IPA guru tidak kesulitan dalam mendesain dan melaksanakan pembelajaran.

Susanto (2013:167) menyatakan,Hakikat pembelajaran sains yang didefinisikan menjadi tiga bagian, yaitu: ilmu pengetahuan sebagai produk, proses, dan sikap. Dari ketiga komponen IPA ini, bahwa IPA juga sebagai prosedur dan IPA juga sebagai teknologi. Akan tetapi, penambahan ini bersifat pengembangan dari ketiga komponen tersebut, pengembangan prosedur dari proses, sedangkan teknologi dari aplikasi konsep dan prinsipprinsip IPA sebagai produk.

Dari pendapat tersebut, dapat disimpulkan bahwa pembelajaran IPA merupakan bagian dari produk, proses serta sikap sebagai suatu kegiatan pembelajaran untuk memahami alam semesta melalui pengamatan.

Berdasarkan hasil obeservasi yang dilaksanakan pada tanggal 09 Januari 2018 di tujuh SD Negeri Gugus I Kecamatan Kuta Utara, lima SD Negeri lainnya masih menerapkan Kurikulum 2006 (KTSP), khususnya pada siswa kelas V mata pelajaran IPA. Pada mata pelajaran IPA menunjukan hasil belajar yang masih dibawah kreteria ketuntasan minimal (KKM). Adapun beberapa penyebab rendahnya hasil belajar IPA, diantaranya masih menerapkan model pembelajaran konvensional dengan proses pembelajaran yang didominasi oleh guru, kurang aktifnya siswa dalam proses pembelajaran yang terlihat dari; 
minimnya pertanyaan-pertanyaan yang dilontarkan siswa kepada guru, kurangnya pendapatpendapat yang muncul dari siswa saat proses pembelajaran, dan kurang mampunya siswa dalam menjelaskan pendapatnya secara logis. Hal ini dikemukakan oleh guru mata pelajaran IPA kelas V di SD No. 4 Dalung yang mengatakan bahwa, keaktifan siswa dalam hal bertanya dan menjawab pertanyaan guru masih minim. Siswa seakan malu bertanya dan takut untuk menjawab pertanyaan yang diberikan oleh guru.

Masih rendahnya kemampuan bertanya dan mengemukakan pendapat siswa, mengakibatkan guru tidak mengetahui apakah semua siswa sudah memahami materi tersebut atau belum, dan guru pun menyimpulkan bahwa semua siswa telah memahami materi tersebut. Selain itu, belum maksimalnya persiapan guru dalam hal penggunaan media pembelajaran, dimana media pembelajaran yang digunakan pada saat proses pembelajaran berlangsung adalah buku paket. Menurut Wati (2016:3) "media pembelajaran merupakan alat dan teknik yang digunakan sebagai perantara komunikasi antara guru dan siswa". Hal ini mengakibatkan siswa kurang termotivasi, dan masih lambatnya siswa untuk menangkap dan menyerap materi tertentu yang sedang diajarkan, sebab siswa hanya disajikan konsepkonsep IPA yang bersifat abstrak sehingga siswa kurang dapat mengembangkan pola pikirnya.

Hal tersebut diperkuat dengan hasil belajar siswa, dimana hasil pencatatan dokumen observasi yang dilakukan menunjukkan bahwa nilai hasil belajar mata pelajaran IPA kelas $\mathrm{V}$ pada semester I belum optimal bila dibandingkan dengan KKM yang ditentukan yaitu 75 untuk mata pelajaran IPA. Dari data hasil belajar siswa semester I menunjukan $39 \%$ hasil belajar siswa belum mencapai Kriteria Ketuntasan Minimal (KKM) atau nilai hasil belajar siswa kurang dari 75. Hal ini diungkapkan oleh wali kelas $\mathrm{V}$ pada mata pelajaran IPA. Menurut Swarjawa (2013) salah satu hal yang perlu dipertimbangkan adalah pemilihan model pembelajaran yang tepat. Model dalam pembelajaran menjadi sangat berpengaruh terhadap hasil belajar IPA. Pemilihan model pembelajaran harus disesuaikan dengan materi pelajaran yang disampaikan sehingga terciptanya proses pembelajaran yang aktif. Salah satu model pembelajaran yang cocok diterapkan yaitu model pembelajaran Probing Prompting.

Menurut Suyatno (2009) model pembelajaran probing prompting merupakan suatu teknik pembelajaran dengan cara guru menyajikan serangkaian pertanyaan yang sifatnya menuntun dan menggali informasi sehingga terjadi proses berpikir yang mengaitkan pengetahuan setiap siswa dan pengalamannya dengan pengetahuan baru yang sedang dipelajari khususnya dalam pembelajaran IPA. Dalam proses pembelajaran IPA yang mempelajari tentang alam sekeliling sangat erat kaitannya dengan pengalaman kehidupan sehari-hari, sehingga dalam proses mengaitkan pengetahuan dengan pengalaman siswa menjadi lebih cepat. Proses tanya jawab yang dilakukan dalam model pembelajaran ini dengan menunjuk siswa secara acak sehingga setiap siswa harus berpartisipasi aktif, siswa tidak bisa menghindar dari proses pembelajaran.

Peranan model pembelajaran ini menjadi jalan alternatif untuk mempermudah siswa melakukan akomodasi dan membangun pengetahuannya sendiri. Siswa mengkontruksi sendiri konsep, prinsip, dan aturan menjadi pengetahuan baru. Aktivitas siswa yang diharapkan dalam pembelajaran adalah siswa dapat melakukan observasi (dengan cara mengamati, mengukur, atau mencatat data, menjawab pertanyaan, dan mengajukan pertanyaan atau sangggahan). Dalam penerapan model pembelajaran probing prompting pada mata pelajaran IPA di kelas terdapat dua aktivitas yang saling berhubungan, yaitu aktivitas siswa yang meliputi aktivitas berpikir dan fisik yang berusaha membangun pengetahuannya dan aktivitas guru yang berusaha membimbing siswanya. Kegiatan ini dapat mendorong siswa untuk lebih aktif dalam pembelajaran, khususnya pada pembelajaran IPA, yang menantang serta memotivasi siswa dalam belajar sehingga dapat meningkatkan hasil belajar IPA siswa.

Penerapan model ini, dibantu dengan media pembelajaran multimedia. Dimana menurut Zainiyati (2017:172) "multimedia merupakan perpaduan berbagai bentuk media secara bersamaan seperti teks, gambar, video, dan lain sebagainya yang kesemuanya saling bersinergi untuk mencapai tujuan pembelajaran yang dirumuskan sebelumnya". 
Dengan penggunaan media ini dapat membantu mengatasi kelemahan dari model yang diterapkan, dapat meningkatkan memotivasi siswa dan membawa pembelajaran IPA kearah yang lebih nyata sehingga siswa lebih aktif dalam pembelajaran serta tidak hanya membayangkan atau mengetahui teori-teori saja tetapi siswa dapat melihat gambaran secara nyata. Pada proses pembelajaran sebelumnya guru menggunakan media buku paket dalam pembelajaran yang mengakibatkan siswa masih lambat dalam menangkap materi sebab siswa hanya disajikan konsep-konsep IPA yang bersifat abstrak yang menjadikan siswa kurang mengembangkan pola pikir melalui potensi dirinya. Penggunaan Multimedia ini akan memberikan pengalaman yang berbeda yang dapat memudahkan proses belajar siswa dan dapat meningkatkan hasil belajar IPA siswa.

\section{Metode}

Jenis penelitian yang dilakukan dalam penelitian ini adalah penelitian kuatitatif dengan desain eksperimen yaitu quasi eksperiment (Eksperimen Semu).

Bentuk desain eksperimen yang digunakan adalah Nonequivalent control group design. Penelitian bentuk ini, biasanya digunakan pada eksperimen yang menggunakan kelas yang sudah terbentuk dan tidak melakukan pengacakan terhadap individu. "Dalam rancangan ini, ada dua kelompok subjek satu mendapat perlakuan dan satu kelompok sebagai kelompok kontrol" (Setyosari, 2013:210). Desain ini melibatkan 2 kelompok yakni kelompok yang mendapatkan perlakuan khusus dengan penerapan model pembelajaran probing prompting berbantuan multimedia sebagai kelompok eksperimen, dan kelompok yang menggunakan pembelajaran dengan model pembelajaran konvensioanl sebagai kelompok kontrol. Rancangan eksperimen semu Nonequivalent control group design diformulasikan sebagai berikut:

\begin{tabular}{|ccc|}
\hline $\mathbf{O}_{1}$ & $\mathrm{X}$ & $\mathbf{O}_{2}$ \\
\hdashline $\mathrm{O}_{3}$ & & $\mathrm{O}_{4}$ \\
\hline
\end{tabular}

Gambar 1. Nonequivalent Control Group Design

(Sumber: Sugiyono, 2015:116)

Pada desain ini kedua kelompok yang diteliti diberikan Pre test. "Pemberian pra tes biasanya digunakan untuk mengukur equivalensi atau penyetaraan kelompok" (Dantes, 2012:97). Berdasarkan hal tersebut, maka dalam penelitian ini pre test hanya digunakan untuk penyetaraan kelompok. Teknik yang digunakan dalam penyetaraan kelompok adalah dengan menggunakan uji-t. Setelah itu peneliti memberikan perlakuan, yaitu dengan memberikan perlakuan berupa model pembelajaran probing prompting berbantuan multimediakepada kelompok eksperimen dan memberikan perlakuan berupa pembelajaran konvensional kepada kelompok kontrol. Setelah diberikan perlakuan, kedua kelompok diberikan post tes untuk mengetahui hasil belajar IPA siswa.

Populasi dalam penelitian ini adalah seluruh siswa kelas $V$ SD Negeri yang menerapkan Kurikulum 2006 (KTSP) di Gugus I Kecamatan Kuta Utara. Terdapat lima SD Negeri dari tujuh SD Negeri yang masih menerapkan Kurikulum 2006, khususnya pada siswa kelas V SD di Gugus I Kecamatan Kuta Utara. Kelas V dari lima SD Negeri terdiri atas 10 kelas dengan 339 orang siswa. Dari populasi yang ada, ditentukan sampel dengan teknik random sampling, yang dirandom adalah kelasnya, sehingga setiap kelas mendapatkan peluang yang sama untuk menjadi sampel penelitian. Terdapat dua sampel dalam penelitian ini, yaitu satu kelas sebagai kontrol dan satu kelas sebagai eksperimen. Sebelum menentukan kelompok kontrol dan kelompok eksperimen. Kedua kelompok sampel yang terpilih, terlebih dahulu dilakukan uji kesetaraan dengan menggunakan uji-t. setelah kedua kelompok tersebut dinyatakan setara selanjutnya dilakuakan random sampling untuk menentukan kelompok eksperimen dan kelompok kontrol dengan hasil kelas $V$ B SD No. 4 
Dalung sebagai Kelompok kontrol dan kelas V B SD No.7 Dalung sebagai kelompok eksperimen. Langkah-langkah eksperimen dalam penelitian ini, terdiri dari 3 langkah, yaitu: (1) langkah tahap persipan dengan melakukan persiapan dan melakukan konsultasi mengenai sumber belajar, media/alat bantu pelaksanaan pembelajaran yang akan digunakan validasi instrument. (2) tahap pelaksanaan penelitian, dilakukan dengan memberikan perlakukan pada kelas eksperimen berupa model pembelajaran probing prompting berbantuan multimedia dan memberi perlakuan berupa pembelajaran konvensional kepada kelas kontrol. Perlakuan dilakukan sebanyak 6 kali, baik di kelas kotrol maupun di kelas eksperimen. Kemudian pada akhir penelitian diberikan post test. (3) tahap akhir eksperimen dalam penelitian ini yaitu menganalisis data hasil penelitian dan melakukan uji hipotesis.

\section{Hasil dan Pembahasan}

Data yang dianalisis dalam penelitian ini adalah data hasil belajar IPA siswa kelas $\mathrm{V}$ SD. Data hasil belajar siswa diperoleh dari hasil post test yang diberikan pada akhir penelitian. Kelompok eksperimen dalam penelitian ini kelas V B SD No. 7 Dalung dan kelas $\checkmark$ B SD No. 4 Dalung sebagai kelompok kontrol. Kelompok eksperimen yang diberikan perlakuan berupa model pembelajaran probing prompting berbantuan multimedia sebanyak 6 kali pertemuan, kemudian pada akhir pertemuan diberikan post test untuk memperoleh data hasil belajar IPA siswa. Ditinjau dari KKM yang ditentukan sekolah yaitu, 75,0 maka banyak siswa kelompok eksperimen yang memperoleh nilai di atas KKM berdasarkan tabel distribusi dan histogram yaitu $80,89 \%$ dan banyak siswa yang memperoleh nilai dibawah KKM sebanyak 19,55\%.

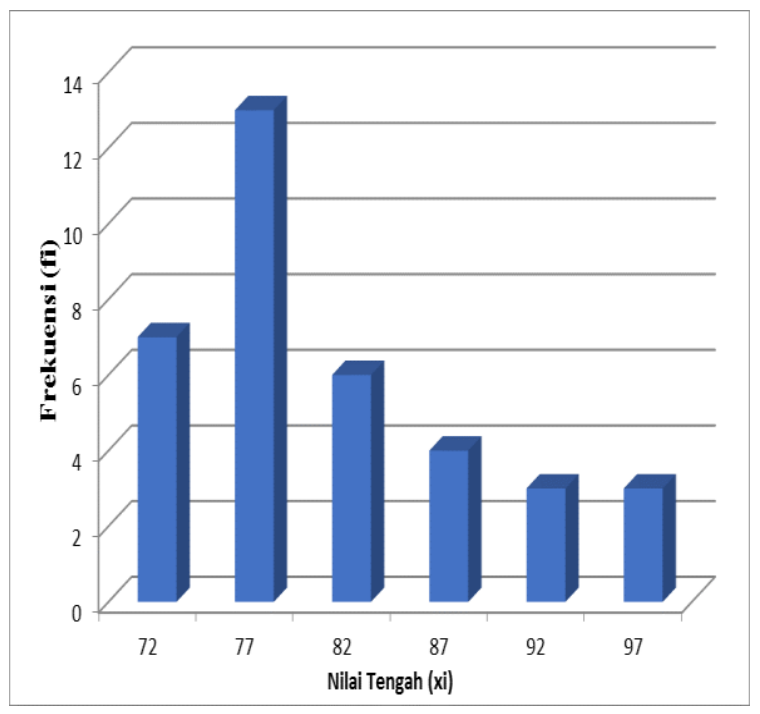

Gambar 1. Histogram Distribusi Frekuensi Nilai Post Test Kelompok Eksperimen(Sumber: Hasil Pengamatan Peneliti)

Berdasarkan, hasil perhitungan data kemudian dianalisis dengan hasil sebagai berikut.

Table 1. Deskripsi Data Hasil Belajar IPA Kelompok Eksperimen

\begin{tabular}{cc}
\hline Statistik & Hasil Belajar IPA \\
\hline Rata - rata & 80,89 \\
Rerata Persentase & $80,89 \%$ \\
Standar Deviasi & 7,66 \\
Varians & 58,73 \\
Nilai Maksimum & 98 \\
Nilai Minimum & 70 \\
\hline
\end{tabular}


Kelompok kontrol pada peneltian ini diberikan perlakuan berupa pembelajaran konvensional sebanyak 6 kali pertemua dan pada akhir penelitian siswa diberikan post test untuk memperoleh data hasil belajar IPA siswa. Data yang diperoleh kemudian digunakan untuk membuat tabel histogram hasil belajar IPA siswa kelompok kontrol, sebagai berikut.

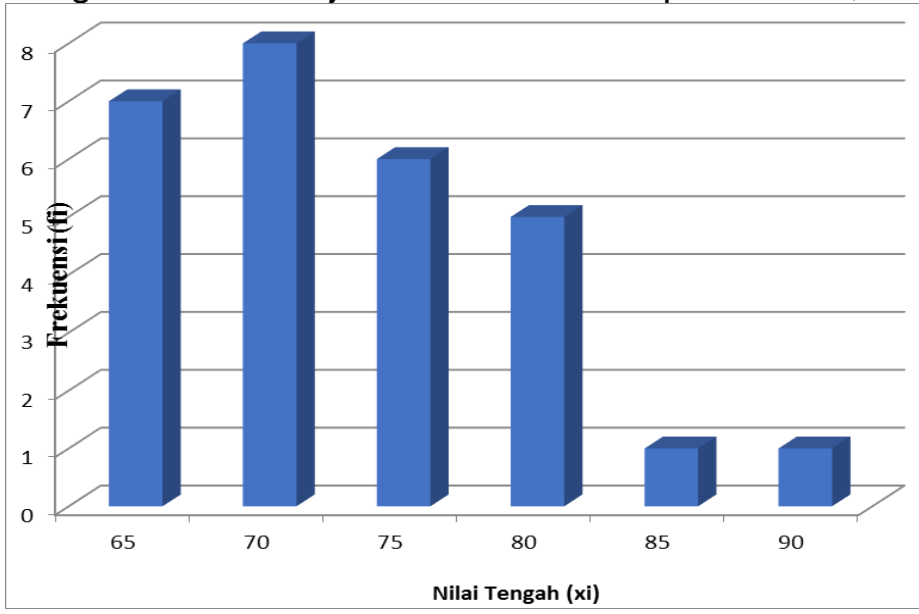

Gambar 2. Histogram Distribusi frekuensi Nilai Post test kelompok kontrol (Sumber. Hasil Pengamatan Penelitian)

Ditinjau dari KKM yang ditentukan sekolah yaitu 75,0 maka banyaknya siswa yang memperoleh nilai di atas KKM berdasrakan table distribusi dan histogram yaitu 39,29\% dan banyak siswa yang memperoleh nilai di bawah KKM sebanyak 60,71\%. Adapun deskripsi data hasil belajar IPA kelompok kontrol dapat disajikan sebagai berikut.

Tabel 2. Deskripsi Data Hasil Belajar IPA Kelompok Kontrol

\begin{tabular}{cc}
\hline Statistik & Hasil Belajar \\
IPA
\end{tabular}

Perolehan hasil perhitungan analisis data yang dilakukan menunjukkan bahwa nilai rerata siswa yang mengikuti pembelajaran menggunakan model pembelajaran probing prompting berbantuan multimedia $X=80,89$ dan siswa yang mengikuti pembelajaran konvensional $X=72,85$, ini menunjukan bahwa nilai rata-rata kelompok eksperimen lebih besar dari nilai rata-rata kelompok kontrol dengan perbedaan nilai sebesar 8,04. Hal tersebut menunjukan bahwa terdapat pengaruh model pembelajaran probing prompting berbatuan multimedia terhadap hasil belajar IPA kelas V SD Gugus I Kecamatan Kuta Utara tahun pelajaran $2017 / 2018$.

Selanjutnya, sebelum dilakukan pengujian hipotesis terlebih dahulu dilakukan uji prasyarat yang meliputi uji normalitas dan uji homogenitas. Pengujian normalitas data dilakukan pada dua kelompok data, meliputi data kelompok yang dibelajarkan melalui model pembelajaran probing prompting dan kelompok yang dibelajarkan dengan pembelajaran konvensional. Uji ini dilakukan untuk mengetahui sebaran data hasil belajar IPA yang akan digunakan dalam pengujian hipotesis, dengan uji Chi-Kuadrat $\left(X^{2}\right)$ pada taraf signifikansi $5 \%$ dan derajat kebebasan $\mathrm{dk}=\mathrm{n}-1$.

Berdasarkan uji normalitas menggunakan uji Chi-Kuadrat dapat disimpulkan bahwa data nilai post test kelompok siswa yang dibelajarkan menggunakan model pembelajaran 
probing prompting berbantuan multimedia dan kelompok siswa yang dibelajarkan menggunakan pembelajaran konvensional berdistribusi normal

Uji homogenitas varian ini dilakukan berdasarkan data hasil belajar IPA yang meliputi data kelompok yang dibelajarkan model pembelajaran probing prompting berbantuan multimediadan data kelompok yang dibelajarkan dengan pembelajaran konvensional.

Uji homogenitas varians menggunakan uji $\mathrm{F}$. Dari hasil perhitungan diperoleh $\mathrm{F}_{\text {hitung }}=$ 1,43, harga ini kemudian dibandingkan dengan harga $F_{\text {tabel }}$ dengan derajat kebebasan pembilang $=36-1=35$ dan derajat kebebasan penyebut $=28-1=27$ dengan taraf signifikasi $5 \%$, sehingga diperoleh $F_{\text {tabel }}=1,88$. Hal tersebut menunjukan bahwa $F_{\text {hitung }}<F_{\text {tabel }}$ $(1,43<1,88)$ yang berarti bahwa varians data hasil belajar IPA antara kelompok eksperimen (kelas V B SD No. 7 Dalung) dan kelompok kontrol (kelas V B SD No. 4 Dalung) adalah homogen. Sehingga untuk menguji hipotesis digunakan rumus polled varians.

Berdasarkan hasil uji hipotesis menggunakan rumus polled varians diperoleh $t_{\text {hitung }}$ $=4,517$ sedangkan pada taraf signifikansi $5 \%$ dan $\mathrm{dk}=62$ diperoleh nilai $\mathrm{t}_{\text {tabel }}=2,000$ sehingga $\mathrm{t}_{\text {hitung }}=4,517>\mathrm{t}_{\text {tabel }}=2,000$. Dengan demikian, hipotesis nol (Ho) ditolak. Hal ini berarti terdapat perbedaan yang signifikan hasil belajar IPA antara kelompok siswa yang dibelajarkan menggunakan model pembelajaran probing prompting berbantuan multimedia dan kelompok siswa yang dibelajarkan menggunakan pembelajaran konvensional siswa kelas V SD Gugus I Kecamatan Kuta Utara tahun ajaran 2017/2018.

Berdasarkan hasil temuan tersebut, dapat dinyatakan kedua kelompok sampel penelitian yang memiliki kemampuan setara, setelah diberikan perlakuan berupa model pembelajaran dengan menggunakan model pembelajaran probing prompting berbantuan multimedia dan mengikuti pembelajaran konvensional diperoleh hasil belajar IPA dalam aspek kognitif yang berbeda. Hal ini dapat dilihat juga dari rata - rata siswa yang mengikuti pembelajaran menggunakan model pembelajaran probing prompting berbantuan multimedia lebih tinggi dibandingkan dengan rata - rata siswa yang mengikuti pembelajaran konvensional. Perbedaan hasil belajar IPA siswa dengan perolehan nilai rerata yang lebih tinggi pada kelompok eksperimen dibandingkan kelompok kontrol disebabkan oleh perlakuan model pembelajaran probing prompting berbantuan multimedia dalam materi IPA yang diberikan pada kelompok eksperimen.

Pada kelompok eksperimen, kegiatan pembelajaran dalam materi IPA menggunakan model pembelajaran probing prompting berbantuan multimedia berjalan dengan optimal dan kondusif, serta para siswa terlibat sangat aktif dan antusias dalam saat proses pembelajaran berlangsung. Hal ini disebabkan karena model pembelajaran probing prompting berbantuan multimedia merupakan suatu inovasi pembelajaran mengajak siswa harus berpartisipasi aktif dan mecari tahu baik itu masalah maupun pemecahan masalah dari pengalamannya dan mengaitkannya dengan materi yang baru siswa pelajari, dengan demikian siswa dituntut untuk memahami materi dan nantinya akan ditunjuk secara acak oleh guru untuk mengetahui pencapaian mereka dalam pembelajaran. Selain itu, selama kegiatan pembelajaran siswa lebih aktif karena kegiatan pembelajaran menggunakan model pembelajaran probing prompting berbantuan multimedia yang memberikan gambaran nyata melalui tayangan materi dengan cara menampilkan video atau gambar, tulisan atau yang lain sebagainnya yang dapat melibatkan siswa dalam interaksi terhadap materi, teman, dan guru sehingga dapat mempermudah siswa untuk mengaitkan dan mengkonstruksikan pengalamannya dengan pengetahuan baru yang sedang dipelajari. Dengan demikian, siswa lebih memahami materi yang diberikan sekaligus mampu mengaplikasikan dalam kehidupan sehari - hari.

Berbeda pada kelompok kontrol, kegiatan pembelajaran konvensional dengan pembelajaran yang lebih banyak menerapkan metode ceramah berjalan kurang optimal. Hal ini disebabkan kurang bervariasinya model dan media pembelajaran, pembelajaran yang masih di dominasi oleh guru sehingga siswa bersikap pasif dalam proses pembelajaran, kurang aktifnya siswa dalam proses pembelajaran yang terlihat dari minimnya pertanyaan dan pendapat yang dilontarkan siswa yang menyebabkan guru sulit mengetahui seberapa pemahaman siswa dalam materi yang diajarkan, khususnya pada materi IPA, dan siswa 
kurang antusias serta siswa sulit mengingat materi yang telah dibelajarkan pada materi pelajaran IPA.

Pembelajaran menggunakan model pembelajaran probing prompting berbantuan multimedia pada materi mata pelajaran IPA dapat memberikan kesempatan untuk lebih berpartisipasinya siswa dalam pembelajaran dan dapat mengetahui seberapa pemahaman dan kemampuan siswa dalam pembelajaran yang terlihat dari pertanyaan maupun pendapat siswa dalam suatu materi. Selain itu siswa dapat bersaing sehat, karena dalam model pembelajaran ini mau tidak mau siswa haru belajar, karena sewaktu-waktu guru memberikan pertanyaan secara acak kepada siswa tentang materi yang sedang dibelajarkan. Dengan demikian, perbedaan hasil belajar IPA siswa dapat terlihat dari cara pembelajaran yang dilakukan pada kedua kelompok tersebut, nilai rerata dan hasil analisis uji hipotesis kelompok siswa yang mengikuti pembelajaran yang menerapkan model pembelajaran probing prompting berbantuan multimedia dan siswa yang mengikuti pembelajaran konvensional.

Hasil temuan pada penelitian ini memiliki persamaan dengan penelitian sebelumnya yang relevan dan memperkuat hasil penelitian yang diperoleh. Hal tersebut didukung oleh hasil penelitian yang dilakukan oleh Hidayatullah (2014) sebagai peneliti menyatakan bahwa penerapan model probing prompting selama proses pembelajaran berlangsung mendorong semua siswa terlibat dan dituntut berpartisipasi aktif,serta memberikan kesempatan kepada siswa untuk mengungkapkan ide-ide baru dalam hal memecahkan masalah ataupun soalsoal yang dilontarkan oleh guru sehingga mampu mengasah kemampuan berpikirnya. Penelitian yang dilakukan oleh Artawan (2017) pembelajaran yang menerapkan model pembelajaran probing prompting dapat mengubah pembelajaran yang awalnya berpusat pada guru menjadi pembelajaran yang berpusat pada siswa. Penelitian yang dilakuakan oleh Swarjawa (2013) yang menyatakan model pembelajaran probing prompting dapat meningkatkan prestasi belajar siswa. Penelitian yang dilakukan oleh Kariadnyani (2016) yang mendukung penggunaan multimedia sebagai media menyatakan bahwa model pembelajaran berbantuan multimedia dapat membantu siswa dalam pembelajaran sehingga tidak dihadapkan pada teori-teori saja tetapi dengan gambaran nyata.

\section{Simpulan dan Saran}

Berdasarkan hasil analisis data, diperoleh nilai rata-rata kelompok eksperimen $X=80,89>X=72,85$ untuk kelompok kontrol yang berarti bahwa terdapat pengaruh model pembelajaran probing prompting berbantuan multimedia terhadap hasil belajar IPA. Hasil uji hipotesis diperoleh $\mathrm{t}_{\text {hitung }}=4,517$ dengan taraf signifikan $5 \%$ dan $\mathrm{dk}=62$ diperoleh $\mathrm{t}_{\text {tabe }}=2,000$. Dengan demikian, $\mathrm{t}_{\text {hitung }}=4,517>\mathrm{t}_{\text {tabel }}(\alpha=0,05,62)=2,000$, sehingga hipotesis nol $\left(\mathrm{H}_{0}\right)$ ditolak dan hipotesis alternatif $\left(\mathrm{H}_{\mathrm{a}}\right)$ diterima, sehingga dapat diiterprestasikan bahwa terdapat perbedaan yang signifikan hasil belajar IPA antara kelompok siswa yang dibelajarkan menggunakan model pembelajaran probing prompting berbantuan multimedia dan kelompok siswa yang dibelajarkan menggunakan pembelajaran konvensional. Dengan demikian dapat disimpulkan bahwa model pembelajaran probing prompting berbantuan multimedia berpengaruh terhadap hasil belajar IPA siswa kelas V SD Gugus I Kecamatan Kuta Utara tahun ajaran 2017/2018.

Adapun saran yang dapat disampaikan kepada siswa, disarankan agar dapat memanfaatkan kesempatan difasilitasi guru dengan berpartisipasi aktif dalam kegiatan pembelajaran, dan diharapkan pembelajaran IPA menjadi lebih baik dan menarik dengan diterapkannya model pembelajaran probing prompting berbantuan multimedia. Kepada guru, disarankan agar lebih kreatif untuk memberikan fasilitas berupa sumber belajar dan diharapkkan dapat menerapkan inovasi-inovasi baru dalam merancang suatu pembelajaran untuk dapat memotivasi dan menfasilitasi potensi yang dimiliki oleh siswa sehingga dapat mencapai hasil belajar yang optimal. Kepada Lembaga sekolah, disarankan agar dapat menggunakan hasil penelitian ini sebagai pendukung sumber belajar guru dalam meningkatkan kualitas pembelajaran dengan menciptakan pembelajaran yang menyenangkan disekolah sehingga sekolah mampu menghasilkan siswa yang memiliki output berkualitas dan sekolah menjadi unggul, dan kepada peneliti lain, disarankan agar 
memanfaatkan hasil penelitian ini sebagai referensi untuk melaksanakan penelitian selanjutnya atau untuk menemukan inovasi kegiatan pembelajaran lainnya yang bermakna dan menyenangkan bagi siswa.

\section{Daftar Pustaka}

Artawan, Ketut Agus, dkk.(2017). "Pengaruh Model Pembelajaran Probing-Prompting Terhadap Hasil Belajar IPA Siswa Kelas V SD". E-Journal PGSD Universitas Pendidikan Ganesha Mimbar PGSD, Vol: 5, No: 2 (hlm. 2-8). Tersedia pada (http://ejournal.undiksha.ac.id/index.php/JJPGSD/article/view/10916). Diakses pada tanggal 05 Januari 2018.

Dantes, Nyoman. 2012. Metode Penelitian. Yogyakarta: Andi.

Hidayatullah, Putunda Al Arif, dkk.(2014). "Pengaruh Model Probing-Prompting Terhadap Kemampuan Berpikir Kritis Siswa Pada Mata Pelajaran IPA Kelas V". e-Journal MIMBAR PGSD Universitas Pendidikan Ganesha, Vol: 2, No: 1 (hlm. 2-9). Tersedia pada (https://ejournal.undiksha.ac.id/index.php/JJPGSD/article/viewFile/3560/2876). Diakses pada tanggal 05 Januari 2018.

Kariadnyani, Era Kd, dkk.(2016). "Pengaruh Model Course Review Horay Berbantuan Multimedia terhadap Hasil Belajar IPA Siswa Kelas V SD". e-Journal PGSD Universitas Pendidikan Ganesha Jurusan PGSD, Vol: 4, No: 1. Tersedia pada (http://ejournal.undiksha.ac.id/index.php/JJPGSD/article/view/7467). Diakses pada tanggal 01 Januari 2018.

Samatowa, Usman. 2016. Pembelajaran IPA di Sekolah Dasar. Jakarta: PT Indeks.

Setyosari, Punaji. 2015. Metode Penelitian Pendidikan \& Pengembangan. Jakarta: Kencana.

Susanto, Ahmad. 2013. Teori Belajar \& Pembelajaran di Sekolah Dasar. Jakarta: Prenadamedia Group.

Sugiyono. 2015. Metode Penelitian Pendidikan (Pendekatan Kuantitatif, Kualitatif, dan R\&D). Bandung: Alfabeta.

Suyatno. 2009. Menjelajah Pembelajaran Inovatif. Sidoarjo: Masmedia Buana Pustaka.

Swarjawa, Eka, dkk.(2013). "Pengaruh Model Pembelajaran Probing-Prompting Terhadap Hasil Belajar IPA Siswa Kelas V SD Negeri 1 Sebatu". Jurusan Pendidikan Guru Sekolah Dasar FIP Universitas Pendidikan Ganesha, (hlm.2-9). Tersedia pada (https://ejournal.undiksha.ac.id/index.php/JJPGSD/article/viewFile/825/698). Diakses pada tanggal 01 Januari 2018.

Wati, Ega Rima. 2016. Ragam Media Pembelajaran. Yogyakarta: Kata Pena. Pendidikan. Jakarta: Prenadamedia Group.

Zainiyati, Husniyatus Salamah. 2017. Pengembangan Media Pembelajaran Berbasis ICT. Jakarta: Kencana. 